\title{
In vitro gene amplification for prenatal diagnosis of congenital adrenal hyperplasia
}

\author{
Gillian Rumsby, John W Honour
}

\begin{abstract}
A simple, rapid, non-radioactive method for detecting homozygous deletions/conversions of the steroid 21-hydroxylase gene is described. In our experience this method will be useful for first trimester prenatal diagnosis of congenital adrenal hyperplasia in $17 \%$ of families of a child with the salt losing form. This test includes an internal control to monitor the success of amplification.
\end{abstract}

Congenital adrenal hyperplasia (CAH) owing to 21hydroxylase deficiency is an autosomal recessive disorder with a prevalence of 1 in 15000 . A number of families with an affected child have requested prenatal diagnosis for this disorder, not with a view to termination but to ensure the initiation of early treatment, possibly in utero, in a second affected child.

The gene defects giving rise to this disorder are heterogeneous and prenatal diagnosis is currently carried out using polymorphic DNA probes. ${ }^{1}$ It has been estimated that approximately $30 \%$ of cases result from deletions of the active 21-hydroxylase gene (CYP21B), while a further $10 \%$ involve conversion of large portions of CYP21B to the inactive pseudogene (CYP21A). Deletions and some gene conversions can be recognised by the loss of CYP21B specific restriction fragments associated with the $5^{\prime}$ end of the gene. The remaining cases of $\mathrm{CAH}$ are likely to be the result of deleterious point mutations in the CYP21B gene.

The move towards the direct detection of these mutations has to be the aim of prenatal diagnosis in order to avoid errors inherent in linkage analysis. We are developing simpler, more direct methods using the in vitro amplification system of Saiki et al. ${ }^{2}$ Here we report a rapid, sensitive, non-radioactive method

Department of Chemical Pathology, University College and Middlesex School of Medicine, Windeyer Building, Cleveland Street, London W1P 6DB.

G Rumsby, J W Honour

Correspondence to Dr Rumsby.

Received for publication 8 December 1989

Revised version accepted for publication 8 May 1990. for the detection of homozygous deletions and gene conversions involving exon 3 of the CYP21B gene, which can be used for the prenatal diagnosis of CAH.

\section{Materials and methods}

CLINICAL MATERIAL

Chorionic villus (CVS) and amniocyte cultures were kindly supplied by Mrs E Young, The Hospital for Sick Children, London. They were stored frozen at $-20^{\circ} \mathrm{C}$ until analysed. DNA was isolated from leucocytes and CVS by standard methods. ${ }^{34}$ In addition, samples of CVS and amniocytes were prepared using the rapid method described by Kogan et al. ${ }^{5}$

\section{METHODS}

Oligonucleotides (table (a)) complementary to sequences flanking exon 3 were synthesised by the phosphoramidite method and purified on Oligonucleotide Purification Cartridges (Applied Biosystems).

DNA, $1 \mu \mathrm{g}$ (leucocyte, CVS) or $10 \mu \mathrm{l}$ final lysis solution (amniocytes and CVS), was subjected to 30 cycles of amplification using the Hybaid Intelligent Heating Unit (Hybaid Ltd). Reaction mix, final volume $0.1 \mathrm{ml}$, was as follows: $10 \mathrm{mmol} / 1 \mathrm{Tris}-\mathrm{HCl}$, $\mathrm{pH} 8.3,50 \mathrm{mmol} / \mathrm{l} \mathrm{KCl}, 2 \mathrm{mmol} / \mathrm{l} \mathrm{MgCl}_{2}, 0.01 \%$ gelatin, $1 \mu \mathrm{mol} / 1$ each oligonucleotide primer, 0.2 $\mathrm{mmol} / \mathrm{l}$ each dATP, dCTP, dGTP, and TTP, overlayed with $100 \mu \mathrm{l}$ paraffin oil. After denaturation at $94^{\circ} \mathrm{C}$ for 10 minutes one unit of $T a q$ polymerase (Amplitaq, Perkin Elmer Cetus) was added and 10 cycles carried out (one cycle being 0.15 minutes at $58^{\circ} \mathrm{C}, 0.5$ minutes at $72^{\circ} \mathrm{C}$, and 0.01 minutes at $95^{\circ} \mathrm{C}$ ). After addition of another unit of enzyme a further 20 cycles were carried out. Then $10 \mu \mathrm{l}$ of the final

Oligonucleotides used as primers and probes.

(a) Oligonucleotide primers

5' CTCCTGCAGACAAGCTGGTG 3'

5' GAACTCCTGGGTCAGCTGCT 3

Oligonucleotide probes

(b) 5' CCAGAGCAGGGAGTAGTCTC 3'

(c) 5' AGAGCAGAGACCAACGACAG 3 
reaction product was run on a $4 \%$ FMC Nusieve agarose (ICN Biomedicals Ltd) mini-gel containing ethidium bromide $(0.5 \mu \mathrm{g} / \mathrm{ml})$ at $60 \mathrm{~mA}$ for one hour and visualised under UV light.

Oligonucleotide probes specific for the CYP21A and CYP21B genes respectively were end labelled with $\left[{ }^{32} \mathrm{P}\right]$ ATP (NEN, $>5000 \mathrm{Ci} / \mathrm{mmol}$ ) using polynucleotide kinase (Pharmacia) according to manufacturer's instructions.

The PCR amplified product was blunt end ligated into SmaI digested M13Mp18RF1. Several recombinant clones were selected for further analysis. Sequencing was carried out using the Sequenase version 2.0 DNA sequencing kit (USB) and samples separated on $6 \%$ polyacrylamide gels $(20 \times 40 \mathrm{~cm})$ at 30 watts for 3.5 hours.

\section{Results}

After in vitro amplification of the 21 hydroxylase genes, two fragments of size 150 and 158 base pairs (bp) were produced. The origin of these bands was established by the following methods: (1) amplification of cloned DNA containing either the CYP21A or CYP21B gene alone; (2) amplification of DNA from the leucocytes of patients shown by restriction enzyme analysis to have a homozygous deletion of the CYP21A or CYP21B gene; (3) hybridisation with specific probes; (4) sequencing data.

\section{AMPLIFICATION OF CLONED DNA}

The results obtained are shown in fig 1A. Amplification of exon 3 of the CYP21B gene gave rise to a band of $158 \mathrm{bp}$ (lane 2) whereas that of the CYP21A produced a band of $150 \mathrm{bp}$ (lane 1). A third, higher molecular weight band (approximately $170 \mathrm{bp}$ ) was present in a normal subject (lane 3 ) and was also seen in patients who are heterozygous for a deletion of CYP21B (data not shown). This band is not seen in patients with homozygous deletions of the CYP21B (lanes 4 to 6) or CYP21A (lanes 7 and 8).

HYBRIDISATION WITH SPECIFIC PROBES

Oligonucleotide probes specific for the CYP21B (table (b)) or CYP21A (table (c)) gene were hybridised to Southern blots of amplified DNA from both patients and cloned DNA samples. The CYP21B specific probe hybridised only to those samples with a $158 \mathrm{bp}$ band (fig 1B, lanes 2, 3, 7, 8) and not to the $150 \mathrm{bp}$ band. Conversely the CYP21A specific oligonucleotide hybridised only to those samples which contained the 150 bp band (fig 1C, lanes $1,3,4,5,6$ ).
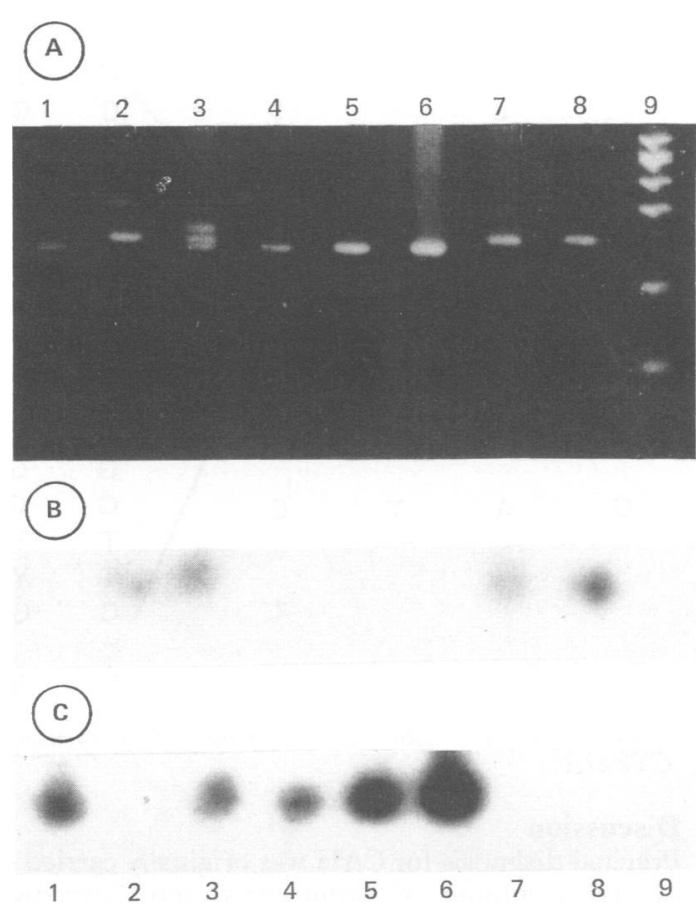

Figure 1 Agarose gel electrophoresis $(A)$ and Southern blot analysis of PCR product. Hybridisation with $C Y P 21 B$ specific (B) and CYP21A specific (C) oligonucleotides. Lane 1 cloned CYP21A, lane 2 cloned CYP21B, lane 3 normal subject, lanes $4,5,6 C A H$ patients homozygous for a deletion of $C Y P 21 B$, lanes 7,8 non-CAH patients homozygous for deletions of CYP2IA, lane $9 \Phi X 174$ RF DNA/HaeIII molecular weight markers.

\section{SEQUENCING DATA}

The sequence of the $150 \mathrm{bp}$ band was identical to that published for exon 3 of the CYP21A gene, showing an 8 bp deletion and two other point mutations (fig 2). A second clone had the sequence of the CYP21B gene (fig 2).

\section{CVS AND AMNIOCYTES}

Various amounts of CVS DNA were amplified to determine the sensitivity of the method. Under the conditions described in the Methods section, a minimum of $0.5 \mu \mathrm{g}$ DNA was needed to see the product clearly on the gel. The sensitivity, however, can be increased by application of a greater volume of product to the gel or decreasing the reaction volume.

The rapid DNA preparations for CVS and amniocytes, requiring lysis by sodium hydroxide or boiling, were also used successfully. 


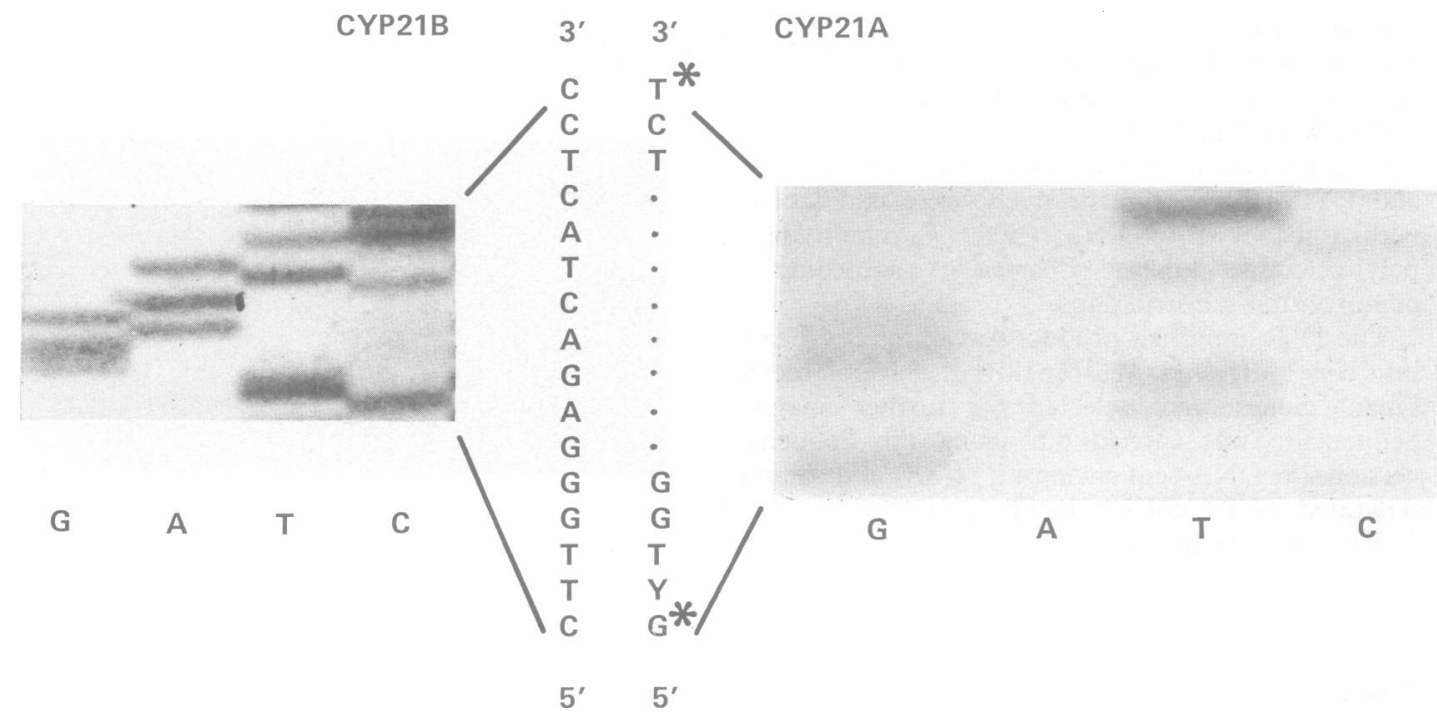

Figure 2 Sequence data of the $158 \mathrm{bp}$ and 150 bp fragments showing the 8 bp deletion and two point mutations $\left({ }^{*}\right)$ characteristic of CYP21A.

\section{Discussion}

Prenatal diagnosis for $\mathrm{CAH}$ was originally carried out by HLA typing of amniocytes and later by a combination of HLA typing and measurement of amniotic fluid 17-hydroxyprogesterone levels. These techniques have three major drawbacks: they cannot be carried out until 16 to 18 weeks' gestation, misdiagnosis may occur with HLA typing owing to recombination and to false negative interaction with antisera, and, finally, 17-hydroxyprogesterone levels are not reliably raised in non-salt losing $\mathrm{CAH}^{6}{ }^{6}$

First trimester diagnosis using DNA analysis of chorionic villus biopsy has been reported for CAH arising from a deleted CYP21B gene ${ }^{7}$ and from undefined defects, ${ }^{1}$ in the latter cases using a combination of probes for 21-hydroxylase, C4, HLA-B, and HLA-DR.

The in vitro amplification method described in this paper can be used in those situations where a homozygous gene deletion or conversion involving exon 3 is present, the loss of the $8 \mathrm{bp}$ fragment in this exon leading to a frameshift mutation and premature termination of mRNA. In our experience the PCR analysis described here is useful in $17 \%$ of our patients with classical salt wasting CAH (six of 36). The simultaneous amplification of the CYP21A gene acts as an essential internal control for the amplification process. The third higher molecular weight band seen in normal subjects and non-deleted CAH haplotypes is the result of the formation of heteroduplexes between the CYP21A and CYP21B fragments (unpublished data), heteroduplex formation being a recognised PCR artefact. ${ }^{8}$ Further tests will define the genetic basis of $\mathrm{CAH}$ in other patients.
In view of a recent report that non-pathological point mutations in the primer region can lead to false negative results, ${ }^{9}$ it would seem prudent to carry oug the amplification steps using more than one set of primers. This can easily be accommodated and we्g would now include an additional amplification of the CYP21B gene alone, using a primer for the region in exon 3 spanning the 8 bp difference.

This work was generously supported by a grant from the Special Trustees of the Middlesex Hospital.

1 Strachan T, Sinnott PJ, Smeaton I, Dyer PA, Harris R. Prenatal diagnosis of congenital adrenal hyperplasia. Lancet 1987;ii:1272-3.

2 Saiki RK, Scharf S, Faloona F, et al. Enzymatic amplification of beta globin genomic sequences and restriction site analysis for diagnosis of sickle cell anaemia. Science 1985;230:1350-4.

3 Woodhead JL, Fallon R, Figueiredo H, Langdale J, Malcolm ADB. Alternative methods of gene diagnosis. In: Davies KE, ed. Human genetic diseases-a practical approach. Oxford: IRL Press, 1986:51-64.

4 Old JM. Fetal DNA analysis. In: Davies KE, ed. Human genetic diseases-a practical approach. Oxford: IRL Press, 1986:1-17.

5 Kogan SC, Doherty M, Gitschier J. An improved method for prenatal diagnosis of genetic diseases by analysis of amplified DNA sequences. $N$ Engl 7 Med 1987;317:985-90.

6 Hughes IA, Dyas J, Riad-Fahmy D, Laurence KM. Prenatal diagnosis of congenital adrenal hyperplasia: reliability of amniotic fluid steroid analysis. $\mathcal{F}$ Med Genet 1987;24:344-7.

7 Reindollar RH, Lewis JB, White PC, Fernhoff PM, McDonough PG, Whitney JB. Prenatal diagnosis of 21-hydroxylase deficiency by the complementary deoxyribonucleic acid probe for cytochrome P-450C21OH. Am F Obstet Gynecol 1988;158:545-7.

8 Nagamine CM, Chan K, Lau YC. A PCR artifact: generation of heteroduplexes. Am F Hum Genet 1989;45:337-9.

9 Fujimura FK, Northrup H, Beaudet AL, O'Brien WE. Genotyping errors with the polymerase chain reaction. $N$ Engl f Med 1990;322:61. 